Keywords:

- Kraka Field

- Ekofisk Formation

- Natural fractures

- Cementation

- Carbonate reservoir

Received:

23. January 2020

Accepted:

25. May 2020

Published online:

19. June 2020

(C) Copyright the authors. This work is licensed under a Creative Commons Attribution 4.0 International License.

\section{A naturally fractured chalk reservoir in the Danian Ekofisk Formation: characteristics, petrography and stable isotope signature of cemented fractures and faults (The Kraka Field, Danish North Sea)}

Aslaug C. Glad ${ }^{1}$, Frédéric Amour ${ }^{1}$, Michael J. Welch ${ }^{1}$, Ole R. Clausen² \& Hamid M. Nick $^{1}$

${ }^{1}$ The Danish Hydrocarbon Research and Technology Centre (DHRTC), Technical University of Denmark, Elektrovej 375, 2800, Kgs. Lyngby, Denmark.

${ }^{2}$ Aarhus University, Department of Geoscience, Høegh-Guldbergs Gade 2, 8000 Aarhus C. Denmark.

E-mail corresponding author (Aslaug C. Glad): Acglad@dtu.dk

Natural fractures occur in chalk from the Kraka Field (Danian Ekofisk Formation, Southern Danish North Sea) and contribute to an increased effective permeability in the reservoir. The majority of fractures are open and act as conduits for hydrocarbons to migrate through. However, some fractures are cemented and thus act as barriers for fluid flow. Predicting porosity and fluid flow in subsurface carbonate reservoirs is challenging, and with a proper understanding of cementation in fractures these subjects are better understood. Further knowledge on cemented fractures can be useful for hydrocarbon exploration and production.

This study investigates cemented fractures, faults and a cataclastic fault zone in chalk cores from the Kraka Field. Emphasis is given to small-scale fractures. These are either partially or fully cemented by mineral precipitates, commonly calcite, and have apparent widths of up to $5 \mathrm{~mm}$. One type of fractures has silica cement along the fracture edge and calcite in the central part, while another type only contains blocky calcite cement. The faults have apparent widths up to $5 \mathrm{~cm}$ and are partially cemented by calcite. The cataclastic fault zone has an apparent width of $25 \mathrm{~cm}$ and is filled with angular fragments of chalk cemented by blocky calcite. Stable isotope analysis of the cement in the fractures and the cataclastic fault zone suggests that they were filled by calcite cement almost simultaneously during burial. The paragenetic sequence of Danian chalk from the Kraka Field is reconstructed and compared with that of other North Sea fields. Based on an investigation of cemented fractures in the Kraka Field, this study provides information on cementation evolution and possible implications for porosity and fluid flow. The majority of Danish

Glad, A.C., Amour, F., Welch, M.J., Clausen, O.R. \& Nick, H.M. 2020: A naturally fractured chalk reservoir in the Danian Ekofisk Formation: characteristics, petrography and stable isotope signature of cemented fractures and faults (The Kraka Field, Danish North Sea). Norwegian Journal of Geology 100, 202008. https://dx.doi.org/10.17850/njg100-2-4. 


\section{Introduction}

North Sea hydrocarbon reserves are situated within chalk reservoirs that are characterised by high porosity and low permeability (Heur, 1984; Megson, 1992). Chalk is composed of accumulated calcareous nannofossils and is usually bioturbated and altered (Håkanson et al., 1974; Hancock, 1975; Surlyk et al., 2003; Fabricius, 2007). Natural fractures can strongly influence the flow properties of a chalk reservoir by enhancing the effective permeability, and ultimately increase recovery (Hardebol et al., 2015; Bisdom et al., 2016). Proper characterisation and prediction of the fracture network throughout a reservoir can thus prove to be economically valuable. Fractures and small faults are generally below seismic resolution (Moreau et al., 2016) and thus sediment cores can provide information on fracture characteristics. Open fractures are most common in naturally fractured chalk reservoirs; however, under certain diagenetic conditions fractures become cemented resulting in reduced fluid-flow paths.

Understanding the diagenetic conditions under which the cement precipitated is a key aspect in predicting and characterising cemented fractures and thus evaluating their influence on reservoir properties. Generally, studies of chalk cementation have focused on the geochemistry of bulk rock compositions due to the often limited cement available from fractures (e.g., Jensenius, 1987; Jørgensen, 1987; Smalley et al., 1992; Hu et al., 2012).

The purpose of this study is to increase understanding of the formation of mineralised fractures and faults in sediment cores from the Danian Kraka Field, Southern Danish North Sea (Fig. 1) through interpretation of macroscopic features, petrography and stable isotope data.

\section{Geological framework}

The Kraka Field is producing from a naturally fractured Danian chalk reservoir and is situated in the Salt Dome Province in the southwestern part of the Danish Sector (Fig. 1). The field represents the first oil discovery in the North Sea by the A-1X well drilled in 1966 (Damtoft et al., 1987).Production, however, did not commence before 1991. Up to 2017 Kraka has produced 5.629 million $\mathrm{m}^{3}$ of oil and 1.559 million $\mathrm{Nm}^{3}$ gas and holds reserves of 1 million $\mathrm{m}^{3}$ of oil (Danish Energy Agency, 2018). The Kraka Field consists of an elongated asymmetric anticlinal chalk structure with a four-way dip closure covering an area of c. $80 \mathrm{~km}^{2}$ (Klinkby et al., 2005; Fig. 2). The anticlinal structure stretches more than $8 \mathrm{~km}$ along its long axis and approximately $5 \mathrm{~km}$ along its short axis (Rasmussen et al., 2005). The crest of the Kraka structure has its top at $1800 \mathrm{~m}$ subsea (Damtoft et al., 1987). The structure is cut by a number of regional faults (Fig. 2). The domal structure associated with the Kraka Field was initiated during the early Late Cretaceous (Vejbæk et al., 2005). The anticlinal structure has been induced through halokinesis and has undergone several development phases caused by the movements of an underlying Permian salt dome initiated during the Triassic and extending to the Early Neogene (RankFriend \& Elders, 2004; Rasmussen et al., 2005). During late Miocene to present, the Danish Central Graben experienced a high rate of subsidence and further deformation and possible fracturing of chalk reservoirs are thought to have occurred in this time interval (Jensenius, 1987; Astratti et al., 2015). The deformation phases have resulted in the reservoir being naturally fractured with large open fractures, both shear and extensional, which act as the main permeability enhancers (Jørgensen \& Andersen, 1991).

Reservoir rocks in the Kraka Field are composed of pure chalk and marly chalk with chert occurring as nodules and layers. The Kraka Field has its main reservoir in the Maastrichtian Tor Formation (Late 

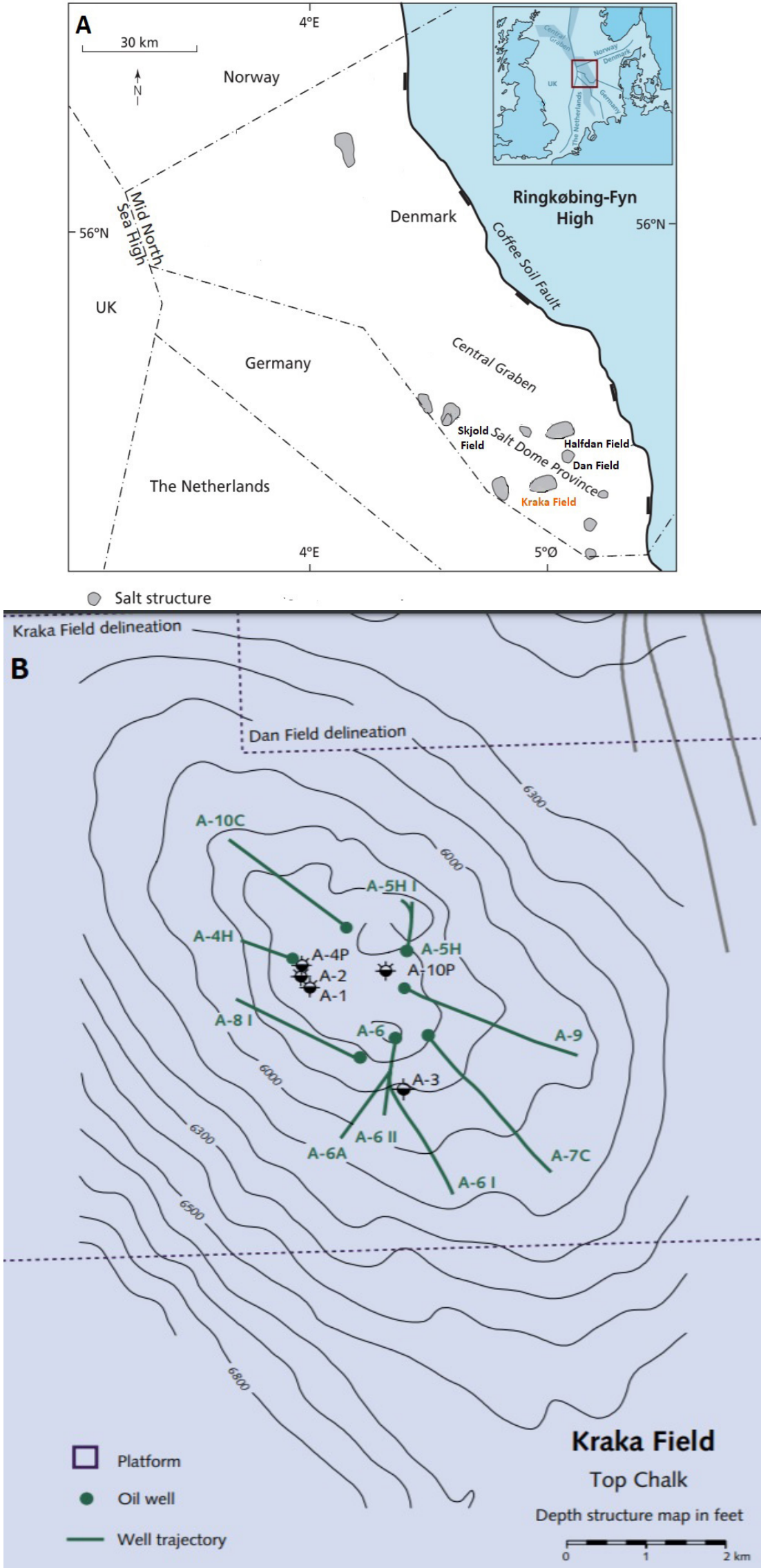

Figure 1. (A) Map of the Danish Central Graben and the main salt structures. The Kraka Field is situated in the southwestern part of the Danish Sector in the Salt Dome Province. (B) Depth structure map of the Top Chalk of the Kraka Field showing the wells and their trajectories. Well A-5P shown in figure 2 is identical to well A-5H on this map. Map adopted from the Danish Energy Authorities (2004). 


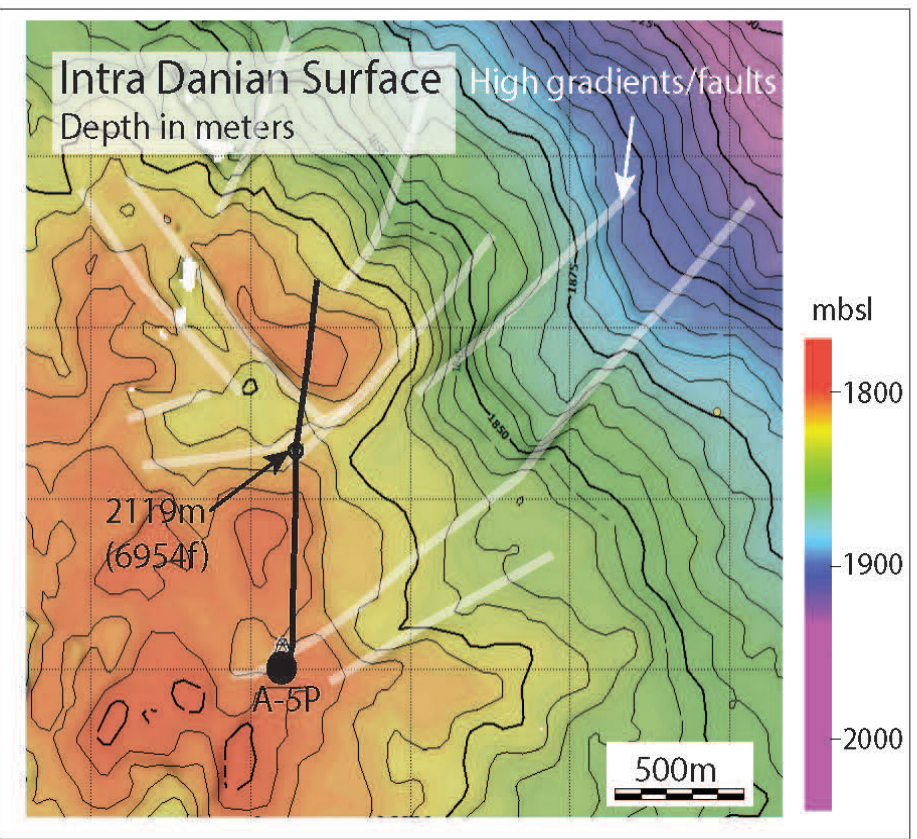

Figure 2. The Intra Danian Surface is a seismic surface positioned where the cataclastic fault zone observed at 6954 feet in A-5P is located. The map shows the depth in metres below sea level with a dip attribute superimposed. The latter gives high topographic gradients a shading emphasising the location of possible faults. The grey lines are interpreted based on the dip and contour patterns, and are suggested to indicate the locations of zones with a high deformation intensity. The coincidence between the cataclastic fault zone and a SW-NE trending deformation zone suggests that the fracture observed is a fault having a offset which is below the seismic resolution.

Cretaceous) and the Danian Ekofisk Formation (Paleocene). The studied cemented fractures are all from the Ekofisk Formation (Fig. 3). Chalk in the Ekofisk Formation of the reservoir is characterised as monomineralic carbonate composed of calcite, silica and small amounts of clay (Abramovitz et al., 2010; Amour et al. 2018; Blinkenberg et al., 2020). The chalk in the reservoir has high porosities of $20-35 \%$ and a low matrix permeability of less than $1 \mathrm{mD}$ in the Ekofisk Formation reservoir, and 2-3 mD in the Tor Formation (Jørgensen \& Andersen, 1991). The natural fracturing of the reservoirs results in an effective permeability of 8-10 mD (Thomasen \& Jakobsen, 1994). The oil column is relatively thin with an average of $30 \mathrm{~m}$ and a maximum of $70 \mathrm{~m}$, while the overlying gas cap has a thickness of $8 \mathrm{~m}$ (Jørgensen \& Andersen, 1991). The reservoir is sealed by late Paleocene marls and claystones (Jørgensen \& Andersen, 1991; Rasmussen et al., 2005).

\section{Methods}

This study includes investigations of sediment cores drilled in the Kraka Field from eight horizontal wells, totalling $267 \mathrm{~m}$ ( $877 \mathrm{ft}$ ). The cores are mostly of good quality, and have a width of around $10 \mathrm{~cm}$. The core sections are mostly coherent with few rubbled sections that may be related to shear fault zones and to intervals of soft oil-bearing chalk which broke into small pieces during drilling. Observed fractures with cement were logged, and their characteristics (type, location, geometry, morphology, size and visible cement) were recorded. Selected cemented fractures were prepared as thin-sections for petrographic analysis. Petrographic inspections of these fractures were done with an Axio Scope. A1 Polarized Light Microscope. 


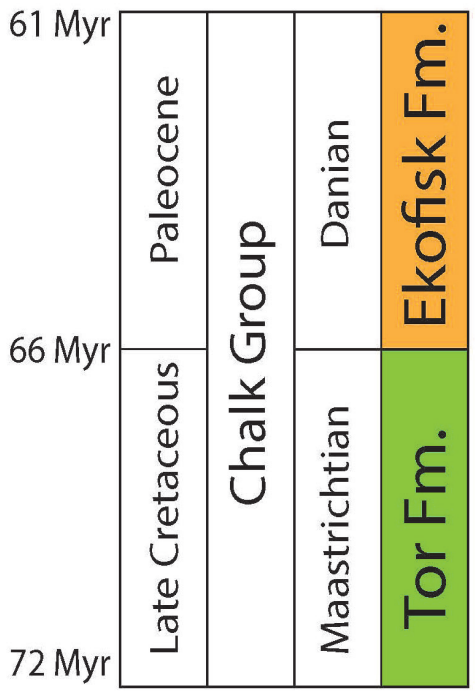

Figure 3. The Kraka Field has its main reservoir in the Maastrichtian Tor Formation (Late Cretaceous) and the Danian Ekofisk Formation (Paleocene). The studied cemented fractures are all from the Ekofisk Formation

Stable isotope analysis of ${ }^{13} \mathrm{C}$ and ${ }^{18} \mathrm{O}$ of eleven samples was carried out by ISO-Analytical. Three types of samples were analysed for their isotopic compositions.

1) Bulk rock, comprising predominantly chalk grains with $>70 \%$ pure calcite (5 samples)

2) Fracture-filling calcite cement, composed of $>95 \%$ pure calcite ( 6 samples from both early cemented fractures and the cataclastic fault zone)

3) Intraparticle cement from a brachiopod shell (3 samples)

All samples were pulverised and for types 2 and 3 the pulverised material was placed under a Leica EZ4 D microscope and the purest calcite crystals were selected using tweezers and small brushes. For each analysis at least $0.1 \mathrm{~g}$ of pure calcite was needed.

\section{Results}

\section{Fracture classification}

The sediment cores drilled in the Kraka Field contain many discontinuities including fractures and faults (Aabø et al., 2019). The fractures include both natural fractures formed by geological processes and induced fractures formed by drilling and coring handling processes (Lorenz \& Cooper, 2018). It was attempted to identify and ignore the induced fractures and focus on the natural fractures that are characterised by cement fill; faults are characterised by evidence of shear displacement (slickensides, offset of bedding, etc.).

Numerous classification systems have been created to categorise discontinuities in sedimetary rocks including fractures; they are built on various parameters such as fracture geometry, origin, structural origin, and physical or electrical properties (e.g., Nelson, 2001). Challenges associated with the establishment of a general classification scheme are related to the great number and variety of discontinuities within different structural settings and lithological units (Schulz \& Fossen, 2008).

The focus of this study is on early cemented natural fractures but we also identified larger-scale cemented shear faults, and one example of a cataclastic fault zone. The distinction between fractures 
and faults is based on the scale of the feature and on the fill: the shear faults have widths of several $\mathrm{cm}$ and show well-developed slickensides, and the cataclastic fault zone has a width of about $30 \mathrm{~cm}$ and contains a breccia with large (up to several $\mathrm{cm}$ ), angular, chalk fragments. We cannot measure the size or the throw of the cataclastic and shear faults directly, but a comparison with similar features in chalk outcrops (e.g. Welch et al., 2014) suggests they may have throws of several metres for the shear faults, or up to several hundred metres, for the cataclastic fault.

\section{Early cemented fractures}

A group of cemented fractures that are either partially or fully cemented by mineral precipitates represent a relatively abundant fracture type in the cores from the Kraka Field with 275 occurrences in wells A3, A4H, A4P, A5H, A5P, A6I and A10P. This fracture type has an apparent width of up to $5 \mathrm{~mm}$, and generally has lengths of up to several centimetres.

The cemented fractures are characterised by being ptygmatically folded with undulating, discontinuous and local curvatures. Fracture propagation perpendicular to the bedding is controlled by the presence of
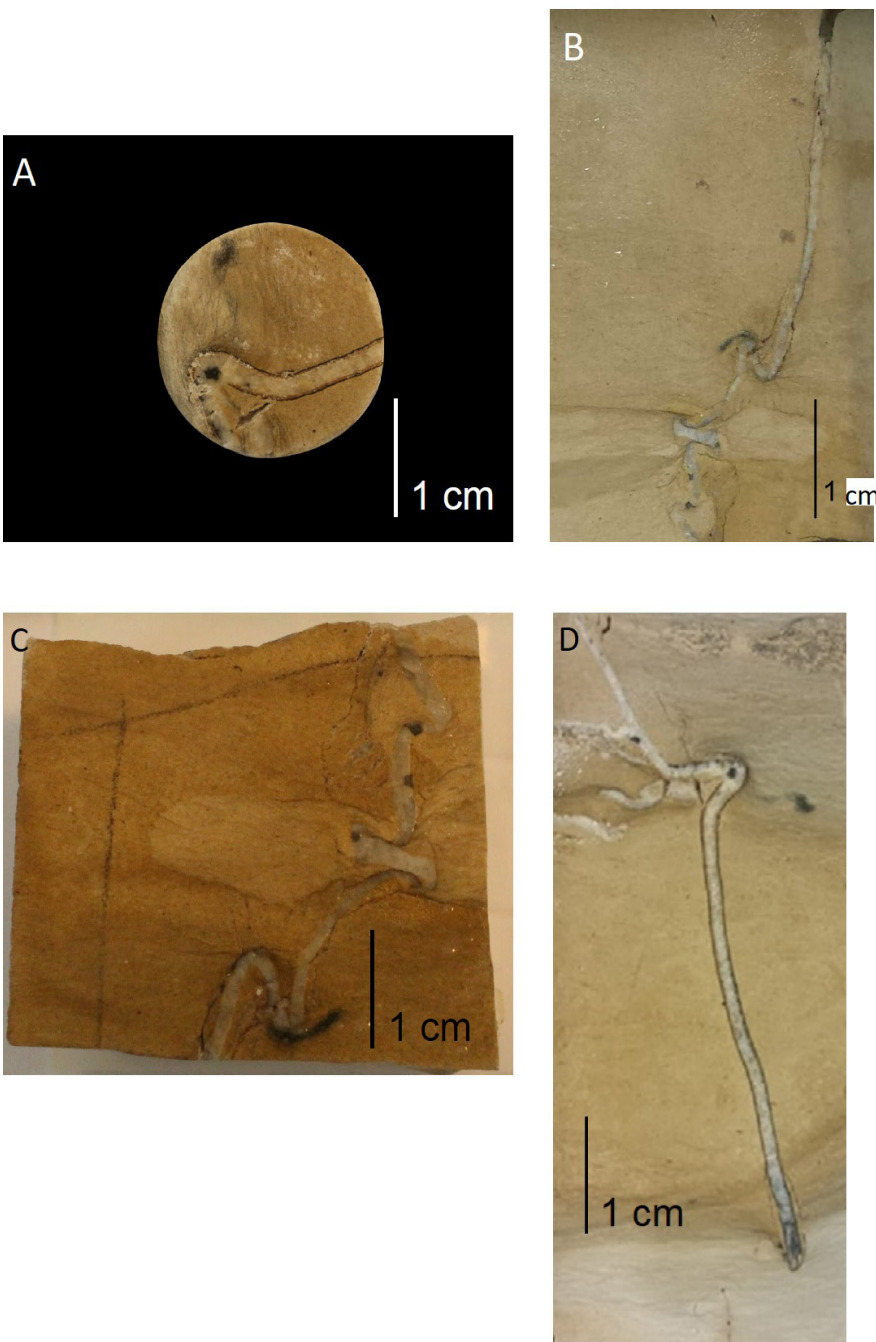

Figure 4. (A) Early cemented fractures observed in cores. Note the undulating, discontinuous and local folds of the fractures. These fractures are cemented by mineral precipitates, and can extend for several $\mathrm{cm}$ in length and have width of up to a few $\mathrm{mm}$. Note how the presence of clay has influenced the fracture propagation seen by changes in colour of the host rock in figure ( $B \& C)$. (D) The ptygmatic fold and the upper part of the fracture propagate against a more clay-rich layer at the top right corner. The fracture is cemented by calcite minerals. 
clay layers as the fractures generally terminate against clay-rich intervals (Fig. 4). These characteristics of the fractures indicate that they formed and cemented early in the lithification process, and can be recognised as early cemented fractures.

Two classes of early cemented fractures are recognised according to the type of fracture-filling cement observed under microscope: The first class shows two phases of silica cement along the fracture edge and calcite cement filling the middle of the fracture. The silica cement is brown in colour and has a homogeneous texture. The outermost silica phase contains clusters of opaque pyrite crystals, and is cut by local microfractures filled by calcite cement (Fig. 5A, B). The central part of the fracture is filled by blocky angular calcite crystals with widths of around 0.2-1 mm. The spatial distribution of the cement phases in the fracture, showing silica cement along the edges and calcite crystals in the inner part of the fractures, suggests an initial silica cementation phase followed by a later calcite cementation representing the latest stage of filling of the fracture. Microfractures filled with calcite and cutting through the silica probably belong to the same phase of mineralisation.The second class of fractures is characterised by one phase of angular blocky calcite crystals filling the fracture (Fig. 5C). The calcite crystals are of variable size from $0.1 \mathrm{~mm}$ to $1 \mathrm{~mm}$ in width with angular to slightly rounded edges.

The silica cementation could be the result of a local presence of silica gel in the host rock as the fractures opened. Prior to further discussing the origin of the silica cement, a brief recall of the chemical processes leading to chert formation is required. After dissolution of calcite by sulphide-oxidising bacteria a few metres below the seafloor, the phase transformation of silica from opal-A to opal-CT and to quartz during burial results from repetitive steps of dissolution-precipitation processes. The dissolution and precipitation of either Opal-A, Opal-CT or quartz in pore space depend on the level of $\mathrm{SiO}_{2}$-saturation in the fluid and also on temperature. Although most of the silica forms close to the surface, the precipitation of quartz likely continues at higher temperature $\left(17-48^{\circ} \mathrm{C}\right)$, i.e., at a greater depth, as suggested by the low $\delta^{18} \mathrm{O}$ values measured in microquartz and megaquartz (Madsen \& Stemmerik, 2010). A $17-48^{\circ} \mathrm{C}$ temperature range corresponds to a depth of $0.6-1.6 \mathrm{~km}$ when considering a temperature gradient of $30^{\circ} \mathrm{C} / \mathrm{km}$ (Japsen et al., 2011). Given the latter depth range, the initial formation of the fractures may resulted in the invasion of the pore space by a $\mathrm{SiO}_{2}$-saturated fluid from which quartz, the later phase in the silica transformation, precipitated. Then, calcite cement likely precipitated during a second step of opening of the fracture later in the burial history.

\section{Faults}

Shear faults are large planar features characterised by relatively sharp boundaries to adjacent host rock and other fractures and show well-developed slickensides indicating a shear displacement. In some cases there are multiple generations of slickensides. There are 35 occurrences in wells $A 3$, A4P, A5H, A5P and A10P. The shear faults are partially cemented by calcite crystals (Fig. 6). They have apertures of between a few $\mathrm{mm}$ to a few $\mathrm{cm}$ and mostly cross the entire drillcore; analogy with observed shear fractures in chalk outcrops suggests a lateral extent varying from a few to several hundred metres (Borradaile, 2015). It was not possible to collect enough pure calcite cement from these features for isotopic analysis.

The sharp contacts and lack of folding seen in the early fractures suggest that the shear fractures formed after lithification of the host rock. The multiple generations of slickensides indicate several phases of reactivation. 

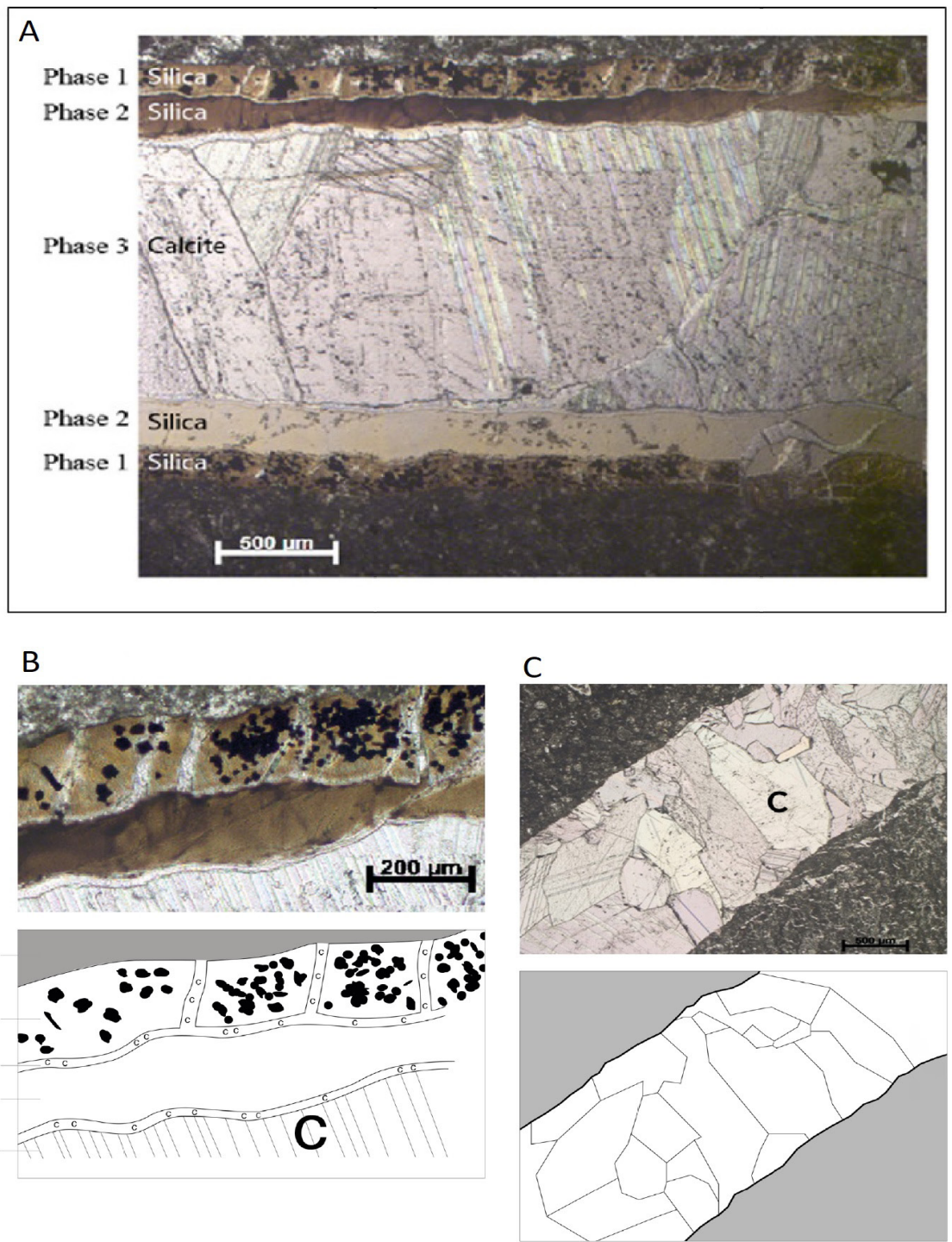

Figure 5. Petrographic analysis of early cemented fractures reveals that the cement filling these fractures can be divided into two groups: The first group shown on figure (A \& B) constitutes fractures that have been filled by two mineral precipitates. Silica cement is present along the edge of the fracture, and occurs in two bands of brownish colour. The outermost phase, shown as a close-up in figure $(B)$ is characterised by clusters of pyrite and calcite crystals cutting the silica oblique to the fracture propagation. Boundaries to the host rock (chalk) are sharp and slightly undulatory. The central part of the fracture is filled by blocky calcite crystals. The calcite cement cutting through the silica suggests that the silica precipitated earliest, perhaps as a result of silica gel being present within the fracture as it opened. (C) illustrates how the second group is cemented by blocky and angular calcite crystals without traces of silica. Boundaries to host rock (chalk) are sharp and slightly undulatory. The C in figure B and Cillustrate the location of calcite crystals. In the drawings the darker grey represent the host rock, and the white zone the cemented fractures.

\section{Cataclastic fault zone}

One cataclastic fault zone was observed in the Kraka cores, in well A5P. This zone has a width of 25 $\mathrm{cm}$, a brecciated appearance and is filled with angular fragments of chalk cemented by blocky calcite crystals (up to $5.5 \mathrm{~cm}$ in size) associated with clusters of pyrite (Fig. 7). The nature and scale of the breccia suggest that the fragments formed by displacement along a fault plane, whicht was then subsequently cemented by calcite. 

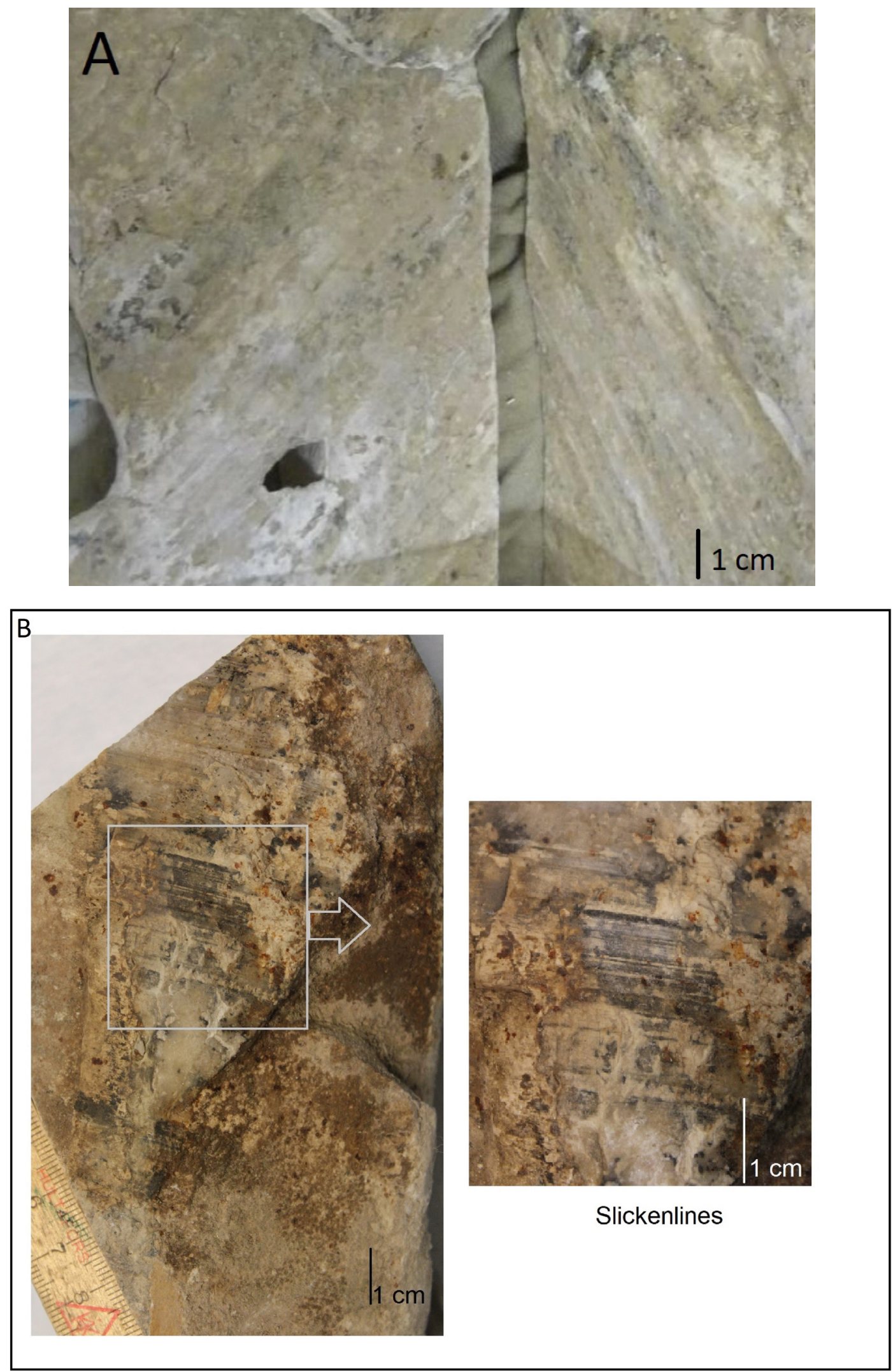

Figure 6. (A) Core picture showing two chalk blocks separated by a sheared fracture with slickenlines intersecting, well A-5P. (B) Close-up of the sheared fracture surface with slickenlines, well A-5P. 

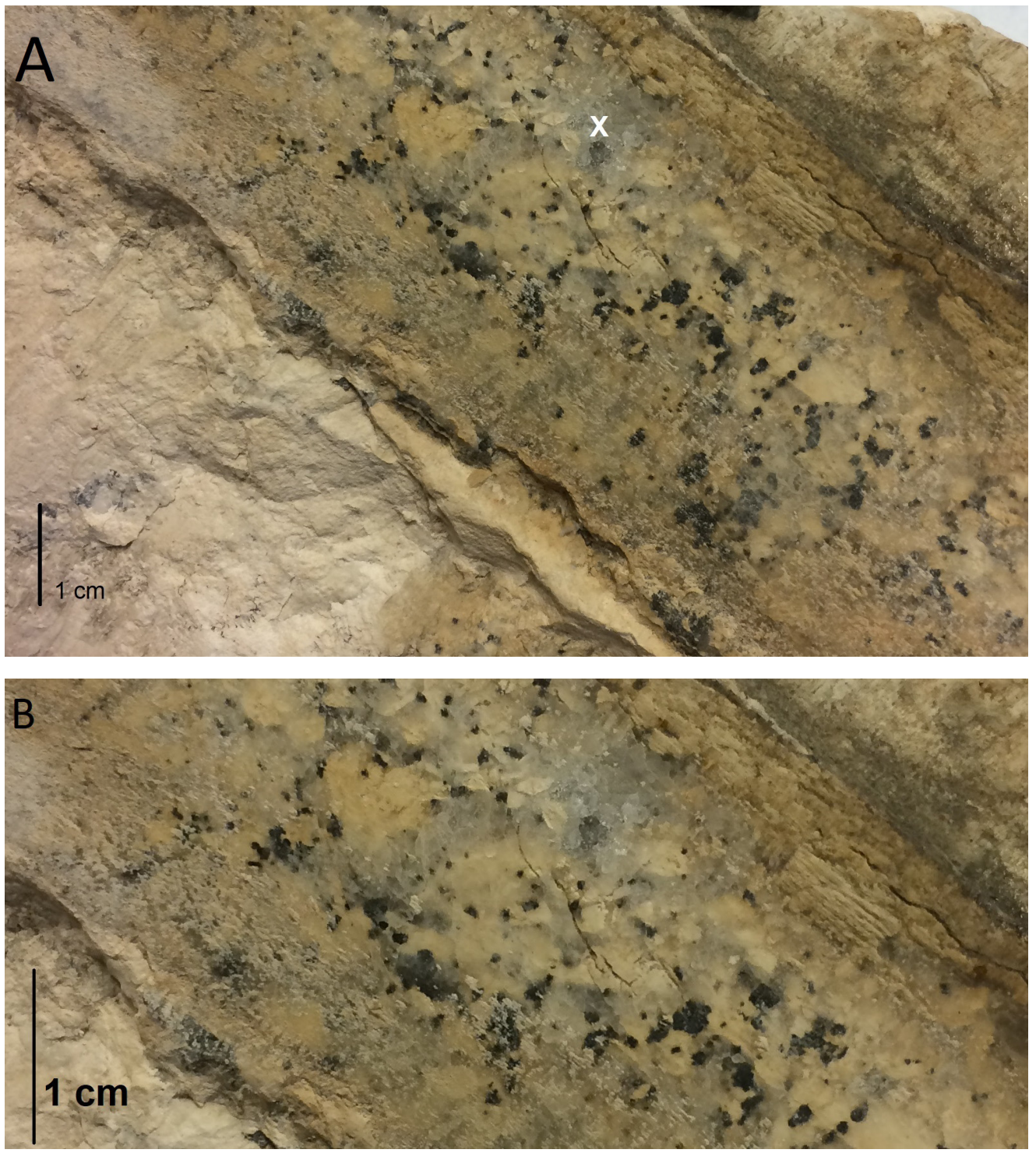

Figure 7. (A) The cataclastic faultzone located in well A5P with a brecciated appearance of intraclasts that have been cemented with calcite and clusters of pyrite. The host rock is seen as white chalk in the lower left corner. The X marks the location where calcite cement has been sampled for isotope analysis. (B) Close-up of the cataclastic fault showing individual angular intraclasts of calcite crystals, chalk and pyrite grains. Also present are two, thin, smear zones indicating repeated shearing during faulting.

\section{Stable isotope analysis}

Within chalk deposits, large pore spaces are generally lacking for blocky calcite crystals to precipitate during burial and therefore only a limited amount of cement is available for sampling. Only fractures and large intraparticle pore spaces are available for recording and preserving the successive cementation phases taking place in chalk from shallow to deep burial, providing a significant amount of material for geochemical analysis.

Fourteen samples have been collected and are analysed for their $\delta^{13} \mathrm{C}$ and $\delta^{18} \mathrm{O}$ compositions (Table 1; Fig. 8): Three samples are from early cemented fractures, three are taken from the cataclastic fault zone, five samples of bulk rock and three samples of calcite cement collected in a brachiopod void. 
Table 1. Overview of $\delta^{13} \mathrm{C}$ and $\delta^{18} \mathrm{O}$ isotope compositions in bulk rock, fracture-filling calcite cement and calcite cement of a brachiopod from the Kraka Field.

\begin{tabular}{cccccc}
\hline Sample number & Sample type & Well & Interval & $\delta^{13} \mathrm{C}(\%$ o) & $\delta^{18} \mathrm{O}(\% \mathrm{o})$ \\
\hline 1 & Fracture-filling cement & $A 2$ & $6057^{\prime} 10$ & 1.10 & -8.90 \\
2 & Fracture-filling cement & $A 2$ & 6056 & 1.31 & -8.40 \\
3 & Fracture-filling cement & $A 2$ & 6056 & 1.30 & -8.27 \\
4 & Cataclastic fault-zone & $A-5 P$ & $6956^{\prime} 2$ & 1.08 & -8.99 \\
5 & Cataclastic fault-zone & $A-5 P$ & $6956^{\prime} 2$ & 1.14 & -8.90 \\
6 & Cataclastic fault-zone & $A-5 P$ & 6956 & 1.15 & -8.01 \\
7 & Bulk rock & $A-5 P$ & $6956^{\prime} 1$ & 1.01 & -3.95 \\
8 & Bulk rock & $A-5 P$ & $6956^{\prime} 1$ & 1.14 & -3.88 \\
9 & Bulk rock & $A 2$ & $6056^{\prime} 9$ & 0.81 & -4.43 \\
10 & Bulk rock & $A 2$ & $6056^{\prime} 9$ & 0.81 & -4.39 \\
11 & Bulk rock & $A 2$ & $6056^{\prime} 9$ & 0.71 & -4.42 \\
12 & Intraparticle cement & $A-4 P$ & $7860^{\prime} 1$ & 0.56 & -9.83 \\
13 & Intraparticle cement & $A-4 P$ & $7860^{\prime} 1$ & -9.53 & -9.85 \\
14 & Intraparticle cement & $A-4 P$ & $7860^{\prime} 1$ & 0.66 & -9.86 \\
\hline
\end{tabular}

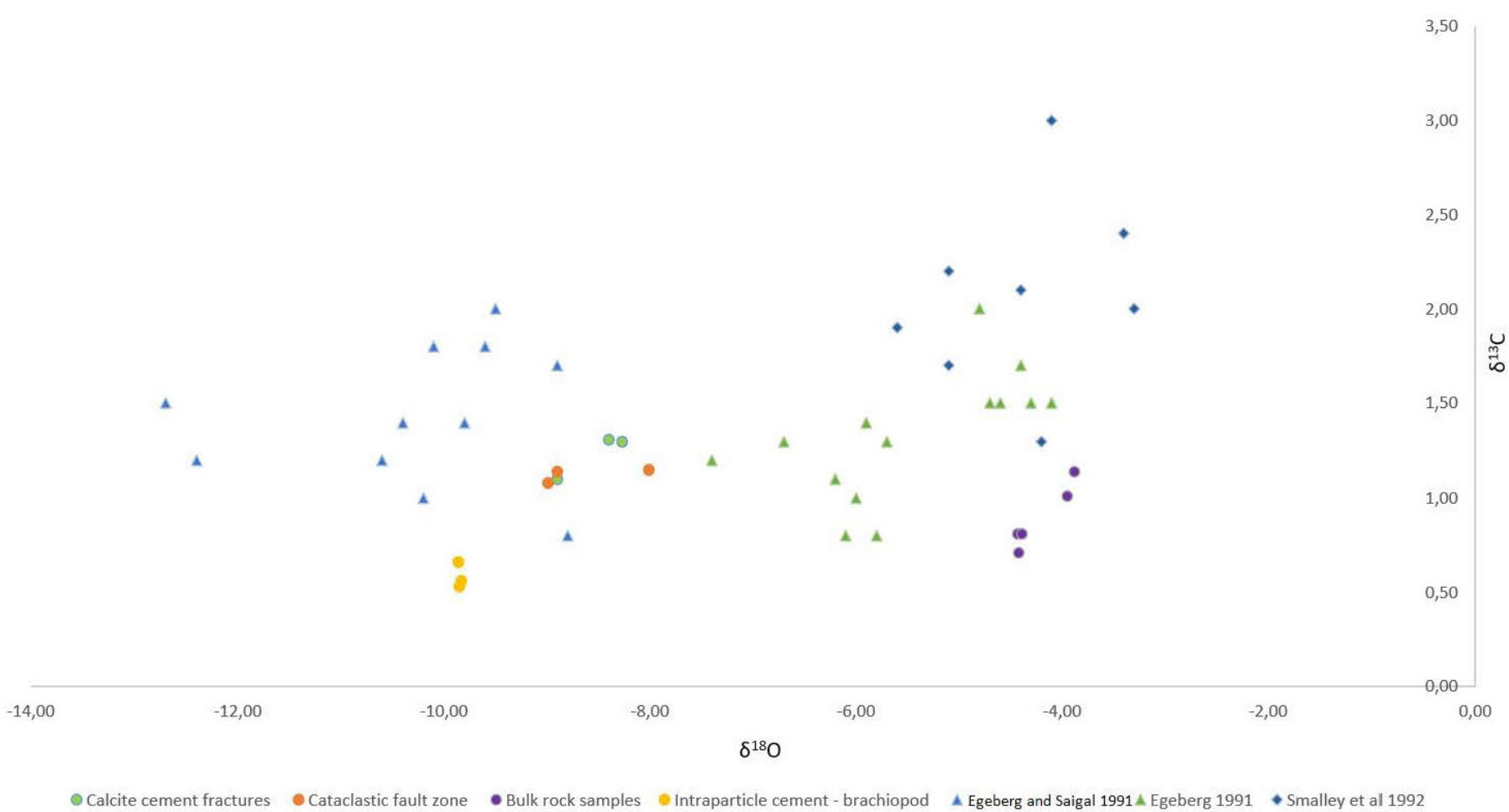

Figure 8. Cross-plot of $\delta^{13} \mathrm{C}$ and $\delta^{18} \mathrm{O}$ values in samples of bulk rock, fracture-filling cement, cement from the cataclastic fault zone and intraparticle cement (brachiopod void) from the Kraka Field. All three groups fall within relatively closed spaced patterns. The isotopic signature of the calcite in the fractures and the cataclastic fault zone is almost identical suggesting precipitation of cement during similar conditions during burial. The stable isotopic results of bulk rock samples from the Dan Field (Danish sector) and Ekofisk Field (Norwegian sector) as well as fracture-filling calcite cement from the Ekofisk and Tor Formation (Norwegian sector) are shown for comparison. 
Comparison of the isotopic values between the four types of samples and previous studies are useful indicators for understanding the relative timing and diagenetic conditions of each cementation phase during burial.

The range of carbon isotope ratios measured in all the samples falls within a relatively narrow field between $+1.31 \%$ and $+0.53 \%$ o. In more detail, the $\delta^{13} \mathrm{C}$ values of the brachiopod cement range from $0.53 \%$ o to $0.66 \%$ o (averaging $+0.58 \%$ ). They are slightly depleted compared with the calcite cement in the fractures. Early cemented fractures have $\delta^{13} \mathrm{C}$ values that vary between $1.10 \%$ and $1.31 \%$, while cement in the cataclastic fault zone has values spanning between $1.08 \%$ ond $1.15 \%$. The average of carbon isotopic values of fracture-filling calcite within the Danian chalk from the Kraka Field is $+1.18 \%$, which is in general accordance with the values measured in the Danian chalk successions located in the Norwegian sector (Egeberg \& Saigal, 1991; Fig. 8) and in the nearby Skjold Field situated in the Danish North Sea (Jensenius et al., 1988).

Analysis of $\delta^{18} \mathrm{O}$ values among the four sample groups shows a larger variability than for the reported $\delta^{13} \mathrm{C}$ values. Calcite cement derived from the brachiopod shell has values ranging between - 9.83\%o and $-9.86 \%$. Early cemented fractures have $\delta^{18} \mathrm{O}$ values between $8.27 \%$ and $-8.90 \%$, while values in the cataclastic fault zone range from - 8.01\% to - 8.99\%o. Values reported in bulk rock samples range from $-3.95 \%$ o to $-4.43 \%$. Bulk rock samples are characterised by the most enriched values of oxygen isotopes, whereas values of the calcite cement in fractures and the brachiopod shell are relative similar.

Comparisons with previous studies indicate that the geochemical data from the bulk rock analysis are in the lower range of the values reported from the Ekofisk Formation in the Norwegian sector (e.g., Egeberg \& Saigal, 1991; Smalley et al., 1992). The calcite cement sampled from fractures and the brachiopod shell also displays $\delta^{13} \mathrm{C}$ and $\delta^{18} \mathrm{O}$ isotope values similar to previous studies (e.g., Hu et al., 2012). Isotopic values are in general accordance with bulk rock analysis of chalk from the nearby Skjold Field (Jensenius, 1987) and other areas of Upper Cretaceous chalk from the Danish North Sea (Jørgensen, 1987). Similarly, previous isotopic analyses of fracture-filling cement are in agreement with the oxygen and carbon isotopes values reported in the present study (Jensenius et al., 1988; Egeberg \& Saigal, 1991). A study by $\mathrm{Hu}$ et al. (2012) presented $\delta^{18} \mathrm{O}$ values of calcite cement in brachiopods from the Upper Cretaceous Chalk in the UK which are within the same range of this study. Jensenius et al. (1988) and Egeberg \& Saigal (1991) reported a decrease in $\delta^{18} \mathrm{O}$ values with increasing burial depth and thereby decreasing porosity of the chalk.

For bulk analysis, buried and outcropping chalk sediments deposited in a basinal setting in the North Sea and in a more proximal setting on the mainland, respectively, display a $0.5-1 \%$ o decrease in $\delta^{13} \mathrm{C}$ values from Maastrichtian to Danian stage (Gilleaudeau et al., 2018). This trend in $\delta^{13} \mathrm{C}$ values has been studied in detail at the Stevns cliffs and in the Dan Field (Scholle et al., 1998) and interpreted as related to climate change. In addition, chalk from the North Sea is enriched in ${ }^{18} \mathrm{O}$ compared with outcrop data, leading to a lowering in the $\delta^{18} \mathrm{O}$ ratio from - $2 \%$ o to $-4.5 \%$. Changes in the oxygen isotope ratio can be interpreted as a difference in burial history of chalk that does not exceed $600 \mathrm{~m}$ for outcrop chalk, while exceeding $1.8 \mathrm{~km}$ for reservoir rocks. This interpretation is in agreement with trends in oxygen isotope ratios observed in Ocean Drilling Programme (ODP) sites and hydrocarbon fields showing that, down to $600 \mathrm{~m}$, values are ranging between $-0.5 \%$ and - 3\%, whereas at $2 \mathrm{~km}$ burial depth $\delta^{18} \mathrm{O}$ values vary between $2.5 \%$ and - 5\% (Fabricius, 2007). Thus, bulk analyses highlight two consistent trends in carbon and oxygen isotopic values from the Danish mainland to the North Sea that are likely controlled by changes in climate conditions and burial history. 


\section{Discussion and conclusions}

A number of small-scale, early cemented fractures as well as some cemented shear faults and one cataclastic fault zone with cement are reported from chalk cores in the Kraka Field. The undulating and folded nature of the cemented fractures and the presence of silica cement suggest that they formed relatively early during burial, either prior to or during mechanical compaction of the chalk (Madsen \& Stemmerik, 2010; Amour et al., 2018). The sharp contacts and nature of the cataclastic and shear faults suggest these formed at a later stage following lithification of the chalk. Chalk in the Kraka reservoir has experienced various types of deformation; i) localised deformation with either no or minor displacement along the fracture planes as shown by the discontinuous, early cemented fractures, and ii) a more pronounced deformation recorded by the cataclastic and shear faults. In addition, stable isotope analyses show similar $\delta^{13} \mathrm{C}$ and $\delta^{18} \mathrm{O}$ values for all fracture- and fault-filling calcite cements. Thus, the early cemented fractures and cataclastic fault zones likely cemented at a similar period during burial, despite their different timing of formation. Fracturing and cementation in the ptygmatically folded early cemented fractures were thus contemporaneous. The host rock fractured and the fractures folded relatively soon after while they were still open, and were then cemented within a relatively short time span. Porosity reduction of the reservoir rock due to cementation of the fractures can be evaluated by comparing the total length of the contorted fracture fill to its present vertical length, and can even provide insights on burial depth during fracturing that can be compared with the oxygen isotope data. One challenge is that the whole fractures are not always constrained within the core, and thus it is an approximation to estimate the amount of compaction and thereby the amount of porosity reduction (e.g., Mallon \& Swarbrick, 2002; Vejbæk et al., 2005).

Sampling for isotopic analysis was done using a binocular microscope in order to select the purest calcite cement from the fractures, so that only calcite crystals were selected for analysis. On the contrary, the bulk rock samples of the chalk matrix that could contain zones with clay and silica were sampled directly from core material. However, the sampling technique could not be differentiated between the different calcite cement phases in the fracture. To do so, microprobe analyses would have been necessary to measure the isotopic values within each zone of the cement (Jeans et al., 2012; 2014; 2016). The microprobe analysis can provide a more accurate picture of the evolution of the diagenetic conditions leading to the cementation and almost complete closure of the fracture. Nevertheless, the present study provides a first detailed insight into the complex cementation history of fractures spanning from shallow to deep burial. The relatively large amount of cement preserved within fracture and intraparticle pores allows access to the diagenetic signal and reconstruct the burial history of chalk within an otherwise cement-free rock matrix. Further investigation of calcite-filled fractures could be done by combining the isotopic data with carbonate staining to provide a new line of investigation on the history of calcite vein filling and to determine their simplicity or complexity (Jeans et al., 2016). By applying staining techniques the paragenetic sequence of calcite cementation in the fractures can be further characterised; this, however, is outside of the scope of this study.

Overall, stable isotope compositions of $\delta^{13} \mathrm{C}$ and $\delta^{18} \mathrm{O}$ of the bulk rock and fracture-filling and intraparticle cements in this study illustrate a depletion in both oxygen and carbon isotopic values. This pattern is typical of a burial trend during which an increase in temperature and pressure with depth leads to more negative oxygen values assuming a closed diagenetic system (e.g., Smalley et al., 1992; Scholle et al., 1998). The negative $\delta^{18} \mathrm{O}$ values in the early cemented fractures, the cataclastic fault zone and the brachiopod relative to the bulk rock therefore suggest that they were all cemented at depth, after burial, by precipitation from a hot fluid. The early cemented fractures and the cataclastic fault zone were probably cemented at a similar time and depth, whereas the brachiopod void was cemented later at greater depth; this may be because the fluids would have had difficulties in pene- 
trating the almost closed pore (cf., Hu et al., 2012). The narrow range of carbon isotope values recorded in the bulk rock and cements could indicate that the cements are derived locally from the dissolution and subsequent precipitation of calcite from the bulk rock along pressure-solution features.

Knowledge of the cement in fractures can thus be of paramount importance when evaluating hydrocarbon fields, and this study presents an insight into the characteristics of these features.

Acknowledgements. The authors kindly acknowledge the Danish Underground Consortium (Total E\&P Denmark, Noreco \& Nordsøfonden) for providing core data and granting the permission to publish this work. This research has received funding from the Danish Hydrocarbon Research and Technology Centre (DHRTC) under the Tight Reservoir Development (TRD) programme.

We are grateful to Trond Slagstad at the Norwegian Journal of Geology for editorial contributions. We would like to thank Christopher Jeans, Henning Dypvik and Kresten Anderskouv for constructive reviews that siginificantly improved the article. ISO Analytical Limited Company (United Kingdom) analysed the samples for stable isotopes. A special thanks to Solomon Seyum for his help on fracture characterisation.

\section{References}

Aabø, T.M., Dramsch, J.S., Würtzen, C.L., Seyum, S. \& Welch, M. 2019: An integrated workflow for fracture characterization in chalk reservoirs, applied to the Kraka Field. Marine and Petroleum Geology 112. https://doi.org/10.1016/j.marpetgeo.2019.104065.

Abramovitz, T., Andersen, C., Jakobsen, F.C., Kristensen, L. \& Sheldon, E. 2010: 3D Seismic mapping and porosity variation of intra-chalk units in the Southern Danish North Sea. In Vining, B.A \& Pickering, S.C. (eds.): Petroleum Geology: From mature basins to new frontiers - Proceedings of the 7th Petroleum Geology Conference, Geological Society of London, pp. 537-548. https://doi.org/10.1144/0070537.

Amour, F., Welch, M., Seyum, S. \& Galdal, E. 2018: Relationships between reservoir properties and production-related changes in effective vertical stress (The Kraka Field, Danish North Sea). Ice Publishing, London, 1-6. https://doi.org/10.1680/eiccf.64072.383.

Astratti, D., Aarre, V., Vejbæk, O.V. \& White, G. 2015: Mapping and time-lapse analysis of South Arne chalk fault network using new developments in seismic dip computation. Geological Society of London, Special Publications 406, 331-358. https://doi.org/10.1144/SP406.10.

Bisdom, K., Bertotti, G. \& Nick, H.M. 2016: The impact of in situ stress and outcrop-based fracture geometry on hydraulic aperture and upscaled permeability in fractured reservoirs. Tectonophysics 690, 63-75. https://doi.org/10.1016/j.tecto.2016.04.006.

Blinkenberg, K.H., Anderskouv, K., Sheldon, E., Bjerrum, C.J., \& Stemmerik, L. 2020: Stratigraphically controlled silicification in Danian chalk and its implications for reservoir properties, southern Danish Central Graben. Marine and Petroleum Geology 115.

https://doi.org/10.1016/j.marpetgeo.2019.104134.

Borradaile, G. 2015: Faults, Chapter 9 in Understanding Geology through maps, Elsevier, pp. 111-139. https://doi.org/10.1016/B978-0-12-800866-9.00009-0. 
Damtoft, K., Andersen, C. \& Thomsen, E. 1987: Prospectivity and hydrocarbon plays of the Danish Central Trough. In Brooks, J. \& Glennie, K.W. (eds.): Petroleum Geology of Northwest Europe. Graham \& Trotman, London, pp. 403-417.

Danish Energy Agency. 2018: Resource assessment and production forecasts. Report 9.

Danish Energy Authority. 2004: Oil and gas production in Denmark, 100 pp.

Egeberg, P.K. \& Saigal, G.C. 1991: North Sea chalk diagenesis: Cementation of chalks and healing of fractures. Chemical Geology 92, 339-354. https://doi.org/10.1016/0009-2541(91)90078-6.

Fabricius, I.L. 2007: Chalk: composition, diagenesis and physical properties. Bulletin of the Geological Society of Denmark 55, 97-128.

Gilleaudeau, G.J., Vögelin, A.R., Thibault, N.R., Moreau, J., Ullmann, C.V., Klaebe, R.M., Korte, C. \& Frei, R. 2018: Stable isotope records across the Cretaceous-Paleogene transition, Stevns Klint, Denmark: new insights from the Chromium isotope system. Geochimica et Cosmochimica Acta 235, 305-332. https://doi.org/10.1016/j.gca.2018.04.028.

Hancock, J. 1975: The sequence of facies in the Upper Cretaceous of northern Europe compared with that in the Western Interior. In Caldwell, W.G.E. (ed.): The Cretaceous System in the Western Interior of North America. Geological Association of Canada Special Paper 13, pp. 83-118.

Hardebol, N.J., Maier, C., Nick, H., Geiger, S., Bertotti, G., \& Boro, H. 2015: Multiscale fracture network characterization and impact on flow: a case study on the Latemar Carbonate Platform. Journal of Geophysical Research: Solid Earth 120, 8197-8222. https://doi.org/10.1002/2015JB011879.

Heur, M. 1984. Porosity and hydrocarbon distribution in the North Sea chalk reservoirs. Marine and Petroleum Geology 3, 211-238. https://doi.org/10.1016/0264-8172(84)90147-8.

Hu, X., Jeans, C.V. \& Dickinson, T. 2012: Geochemical and stable isotope patterns of calcite cementation in the Upper Cretaceous Chalk, Uk: direct evidence from calcite-filled vugs in Brachiopods. Acta Geologica Polonica 62, 143-172. https://doi.org/10.2478/v10263-012-0007-x.

Håkansson, E., Bromley, R. \& Perch-Nielsen, K. 1974: Maastrichtian chalk of north-west Europe a pelagic shelf sediment. In Hsü, K.J. \& Jenkyns, H.C. (eds): Pelagic sediments on land and under the sea. International Association of Sedimentologists Special Publications 1, pp. 211-233. https://doi.org/10.1002/9781444304855.ch9.

Japsen, P., Dysthe, D.K., Hartz, E.H., Stipp, S.L.S., Yarushina, V.M. \& Jamtveit, B. 2011: A compaction front in North Sea chalk. Journal of Geophysical Research 116, B11208. https://doi.org/10.1029/2011JB008564.

Jeans, C.V., Hu, X. \& Mortimore, R.M. 2012: Calcite cements and the stratigraphical significance of marine $\partial 13 \mathrm{C}$ carbonate reference curve for the Upper Cretaceous Chalk of England. Acta Geologica Polonica 62, 173-196. https://doi.org/10.2478/v10263-012-0008-9.

Jeans, C.V., Long, D., Hu, X. \& Mortimore, R.M. 2014: Regional hardening of Upper Cretaceous Chalk in Eastern England, UK: trace element and stable isotope patterns in the Upper Cenomanian and Turonian chalk and their significance. Acta Geologica Polonica 64, 173-196. https://doi.org/10.2478/agp-2014-0023. 
Jeans, C.V., Turchyn, A.V. \& Hu, X. 2016: Sulfur isotope patterns of iron sulfide and barite nodules in the Upper Cretaceous Chalk of England and their regional significance in the origin of coloured chalks. Acta Geologica Polonica 66, 227-256. https://doi.org/10.1515/agp-2016-0010.

Jensenius, J. 1987: High temperature diagenesis in a shallow chalk reservoir, the Skjold Oil Field, Danish North Sea: evidence from fluid inclusions and Oxygen isotopes. American Association of Petroleum Geology Bulletin 71, 1378-1386. https://doi.org/10.1306/703C8083-1707-11D7-8645000102C1865D.

Jensenius, J., Buchhardt, B., Jørgensen, N.O. \& Pedersen, S. 1988: Carbon and Oxygen isotopic studies of the chalk reservoir in the Skjold Oilfield, Danish North Sea: implications for diagenesis. Chemical geology 73, 97-107. https://doi.org/10.1016/0168-9622(88)90009-7.

Jørgensen, L.N. \& Andersen, P.M. 1991: Integrated study of the Kraka Field. Society of Petroleum Engineers 23082, 14 pp. https://doi.org/10.2118/23082-MS.

Jørgensen, N.O. 1987: Oxygen and Carbon isotope compositions of Upper Cretaceous chalk from the Danish sub-basin and the North Sea Central Graben. Sedimentology 34, 559-570. https://doi.org/10.1111/j.1365-3091.1987.tb00786.x.

Klinkby, L., Kristensen, L., Nielsen, E.B., Zinck-Jørgensen, K. \& Stemmerik, L. 2005: Mapping and characterisation of thin chalk reservoirs using data integration: the Kraka Field, Danish North Sea. Petroleum Geoscience 11, 113-124. https://doi.org/10.1144/1354-079304-632.

Lorenz, J.C. \& Cooper, S.P. 2018: Atlas of natural and induced fractures in core. Wiley-Blackwell, 328 pp. https://doi.org/10.1002/9781119160014.

Madsen, H. \& Stemmerik, L. 2010: Diagenesis of flint and porcellanite in the Maastrichtian chalk at Stevns Klint, Denmark. Journal of Sedimentary Research 80, 578-588. https://doi.org/10.2110/jsr.2010.052.

Mallon, A. \& Swarbrick, R. 2002: A compaction trend for non-reservoir North Sea Chalk. Marine and Petroleum Geology 19, 527-539. https://doi.org/10.1016/S0264-8172(02)00027-2.

Megson, J.B, 1992: "The North Sea Chalk Play: exampled from the Danish Central Graben". In Hardman, R.F.P (ed): Exploration Britain: Geological insights for the next decade, Geological Society Special Publication No.67, pp. 247-282. https://doi.org/10.1144/GSL.SP.1992.067.01.10.

Moreau, J., Boussaha, M., Nielsen, L., Thibault, N., Clemens, U.V. \& Stemmerik, L. 2016: Early diagenetic evolution of Chalk in eastern Denmark. The Depositional Record 2, 154-172.

https://doi.org/10.1002/dep2.19.

Nelson, R. 2001: Geologic analysis of naturally fractured reservoirs. Gulf professional publishing, 352 pp. https://doi.org/10.1016/B978-088415317-7/50004-X.

Rank-Friend, M. \& Elders, C.F. 2004: The evolution and growth of Central Graben salt structures, Salt Dome Province, Danish North Sea. In Davies, R.J., Cartwright, J.A., Stewart, S.A., Lappin, M. \& Underhill, J.R. (eds.): 3D seismic technology: application to the exploration of sedimentary basins, Geological Society of London Memoirs 29, pp. 149-163. https://doi.org/10.1144/GSL.MEM.2004.029.01.15. 
Rasmussen, E.S., Vejbæk, O.V., Bidstrup, S. \& Dybkjær, K. 2005: Late Cenozoic depositional history of the Danish North Sea Basin: implications for the petroleum systems in the Kraka, Halfdan, Siri and Nini Fields. In Dorè, A.G. \& Vinding, B.A. (eds.): Petroleum geology: North-West Europe and global perspectives - Proceedings of the 6th petroleum geology conference, Geological Society of London, pp. 1347-1358. https://doi.org/10.1144/0061347.

Scholle, P.A., Albrechtsen, T. \& Tirsgaard, H. 1998: Formation and diagenesis of bedding cycles in uppermost cretaceous chalks of the Dan Field, Danish North Sea. Sedimentology 45, 223-243.

https://doi.org/10.1046/j.1365-3091.1998.0148e.x.

Schultz, R.A. \& Fossen, H. 2008: Terminology for structural discontinuities. American Association of Petroleum Geologists bulletin 92, 853-867. https://doi.org/10.1306/02200807065.

Smalley, P.C., Lønøy, A. \& Råheim, A. 1992: Spatial 87Sr/86Sr variations in formation water and calcite from the Ekofisk chalk oil field: implications for reservoir connectivity and fluid composition. Applied Geochemistry 7, 341-350. https://doi.org/10.1016/0883-2927(92)90024-W.

Surlyk, F., Dons, T., Clausen, C.K. \& Higham, J. 2003: Upper Cretaceous. In Evans, D., Graham, C., Amour, A. \& Bathurst, P. (eds.): The millennium atlas: petroleum geology of the central and northern North Sea, Geological Society of London, pp. 213-233.

Thomasen, J.B. \& Jacobsen, N.L. 1994: Dipping fluid contacts in the Kraka Field, Danish North Sea. Society of Petroleum Engineers 28435, 763-772. https://doi.org/10.2118/28435-MS.

Vejbæk, O.V., Frykman, P., Bech, N. \& Nielsen, C.M. 2005: The history of hydrocarbon filling of Danish Chalk field. In Doré, A.G. \& Vining, B.A. (eds): Petroleum geology: North-West Europe and global perspectives - Proceedings of the 6th petroleum geology conference, Geological Society of London, pp. 1331-1346. https://doi.org/10.1144/0061331.

Welch, M.J., Souque, C., Davies, R.K. \& Knipe, R.J. 2014: Using mechanical models to investigate the controls on fracture geometry and distribution in chalk. In Agar, S.M. \& Geiger, S. (eds.) 2015: Fundamental Controls on Fluid Flow in Carbonates: Current Workflows to Emerging Technologies, Geological Society of London, Special Publications 406, pp. 281-309. 